\title{
KARAKTERISTIK KUALITAS AIR DANAU LIMBOTO, PROVINSI GORONTALO
}

\author{
Krismono, Lismining Pujiyani Astuti, dan Yayuk Sugianti \\ Peneliti pada Loka Riset Pemacuan Stok Ikan, Jatiluhur-Purwakarta \\ Teregistrasi I tanggal: 25 Mei 2007; Diterima setelah perbaikan tanggal: 13 Desember 2007; \\ Disetujui terbit tanggal: 17 Desember 2008
}

\begin{abstract}
ABSTRAK
Danau Limboto terletak pada ketinggian $25 \mathrm{~m}$ di atas permukaan laut yang berada di Kabupaten Gorontalo, Provinsi Gorontalo. Danau ini berfungsi untuk perikanan tangkap, perikanan budi daya, dan pengendalian banjir. Kualitas air merupakan kunci penting bagi kehidupan ikan dan salah satu masukkan penting untuk pengelolaan kegiatan perikanan. Penelitian ini bertujuan untuk mengetahui keadaan kualitas air Danau Limboto. Penelitian ini dilaksanakan pada bulan Maret, Mei, September, dan Nopember 2006. Pengambilan contoh air dilakukan di lima stasiun pengamatan dengan metode survei berstrata. Hasil penelitian menunjukkan bahwa suhu, $\mathrm{pH}$, alkalinitas total, oksigen terlarut, dan karbondioksida bebas Danau Limboto mendukung untuk kegiatan perikanan. Berdasarkan pada tingkat kecerahan, $\mathrm{N}-\mathrm{NO}_{3}, \mathrm{P}-\mathrm{PO}_{4}$, klorofil-a, dan kelimpahan plankton, danau ini termasuk ke dalam perairan eutrofik hingga hipertrofik (subur).
\end{abstract}

KATAKUNCI: $\quad$ karakteristik, kualitas air, Danau Limboto

ABSTRACT: Characteristic of Water Quality at Limboto Lake. By: Krismono, Lismining Pujiyani Astuti, and Yayuk Sugianti

Limboto Lake is located in Gorontalo District, Gorontalo Province at $25 \mathrm{~m}$ above sea level. The lake functions as capture and culture fisheries and flood control. Water quality is an important environmental factors for fisheries management. The objective of this research was to identify the water quality characteristic of Limboto Lake. Research was done at March, May, September, and November 2006. Water samples was taken in each research stations using survey stratified method. The results showed that temperature, $\mathrm{pH}$, total alkalinity, dissolved oxygen, and free carbon dioxide were in the level of supporting the fisheries activity. Based on transparency, $\mathrm{N}-\mathrm{NO}_{3}, \mathrm{P}-\mathrm{PO}$, chlorophylla, and abundance of plankton, the lake was catagorized as eutrophic to hypertrophic waters.

KEYWORDS: characteristic, water quality, Limboto Lake

\section{PENDAHULUAN}

Danau Limboto terletak di Kabupaten Gorontalo, Propinsi Gorontalo pada ketinggian $25 \mathrm{~m}$ di atas permukaan laut (dpl.) dan dikelilingi oleh pegunungan kapur yang gundul, berjarak sekitar $20 \mathrm{~km}$ dari pantai. Luas danau mengalami penurunan dari tahun ke tahun akibat proses pendangkalan. Luas danau pada tahun 1932 tercatat sekitar $7.000 \mathrm{Ha}$, namun pada tahun 2005 tinggal $2.985 \mathrm{Ha}$. Danau ini dimanfaatkan untuk kegiatan perikanan tangkap dan budi daya serta pengendalian banjir. Danau Limboto merupakan danau yang dangkal terletak pada ketinggian yang rendah dan termasuk danau polimiktik (Lehmusluoto, 2000).

Pendangkalan Danau Limboto disebabkan oleh sedimentasi lumpur yang berasal dari aliran Sungai Limboto, penggunaan perangkap ikan yang tidak ramah lingkungan seperti bibilio dan olate serta kegiatan budi daya perikanan. Hasil penelitian Pusat
Penelitian dan Pengembangan Sumber Daya Air menunjukkan bahwa Danau Limboto termasuk danau yang mengalami sedimentasi berat dan pengurangan luas. Selain Danau Limboto, danau yang mengalami sedimentasi berat antara lain Danau Tondano, Danau Tempe (Sulawesi), Danau Jempang, Danau Semayang, dan Danau Melintang (Kalimantan), sedangkan danau yang mengalami pengurangan luas adalah Rawa Pening dan Cidanau di Banten (Anonimus, 2008). Tumbuhan air yang banyak terdapat di Danau Limboto antara lain Ceratophylum demersum, Hydrilla verticillata, Nymphea sp., Utricularia sp., Salvinia auriculata, dan Gramínae (Guilemard dalam Whitten et al., 1988).

Kegiatan perikanan di Danau Limboto meliputi perikanan budi daya dan tangkap. Perikanan budi daya dimulai sekitar 1980-an dengan teknik hampang (jaring tancap). Jenis ikan utama yang dibudidaya adalah ikan nila (Oreochromis niloticus). Hasil 
perikanan tangkap di Danau Limboto antara lain ikan payangka (Ophiocara porocephala), manggabai (Glossogobius giuris), gabus (Channa striata), sepat atau saribu (Trichogaster pectoralis), tawes (Puntius gonionotus), lele (Clarias sp.), nila, mujair ( $O$. mossambicus), dan mas (Cyprinus carpio). Ikan Payangka dan Manggabai merupakan ikan asli Danau Limboto yang keberadaannya mulai berkurang, padahal jenis ikan ini digemari oleh masyarakat sekitar danau.
Kualitas air seperti oksigen terlarut, alkalinitas, dan karbondioksida bebas merupakan parameter kunci untuk kehidupan ikan (Effendi, 2002), sedangkan tingkat kecerahan air, konsentrasi $\mathrm{N}-\mathrm{NO}_{3}$, konsentrasi $\mathrm{P}-\mathrm{PO}_{4}$, dan kelimpahan plankton merupakan parameter tingkat kesuburan perairan. Data tersebut dapat menjadi informasi yang menggambarkan keadaan perairan di Danau Limboto. Data mengenai kondisi perairan diharapkan dapat menjadi bahan pertimbangan bagi pengelolaan perairan tersebut.

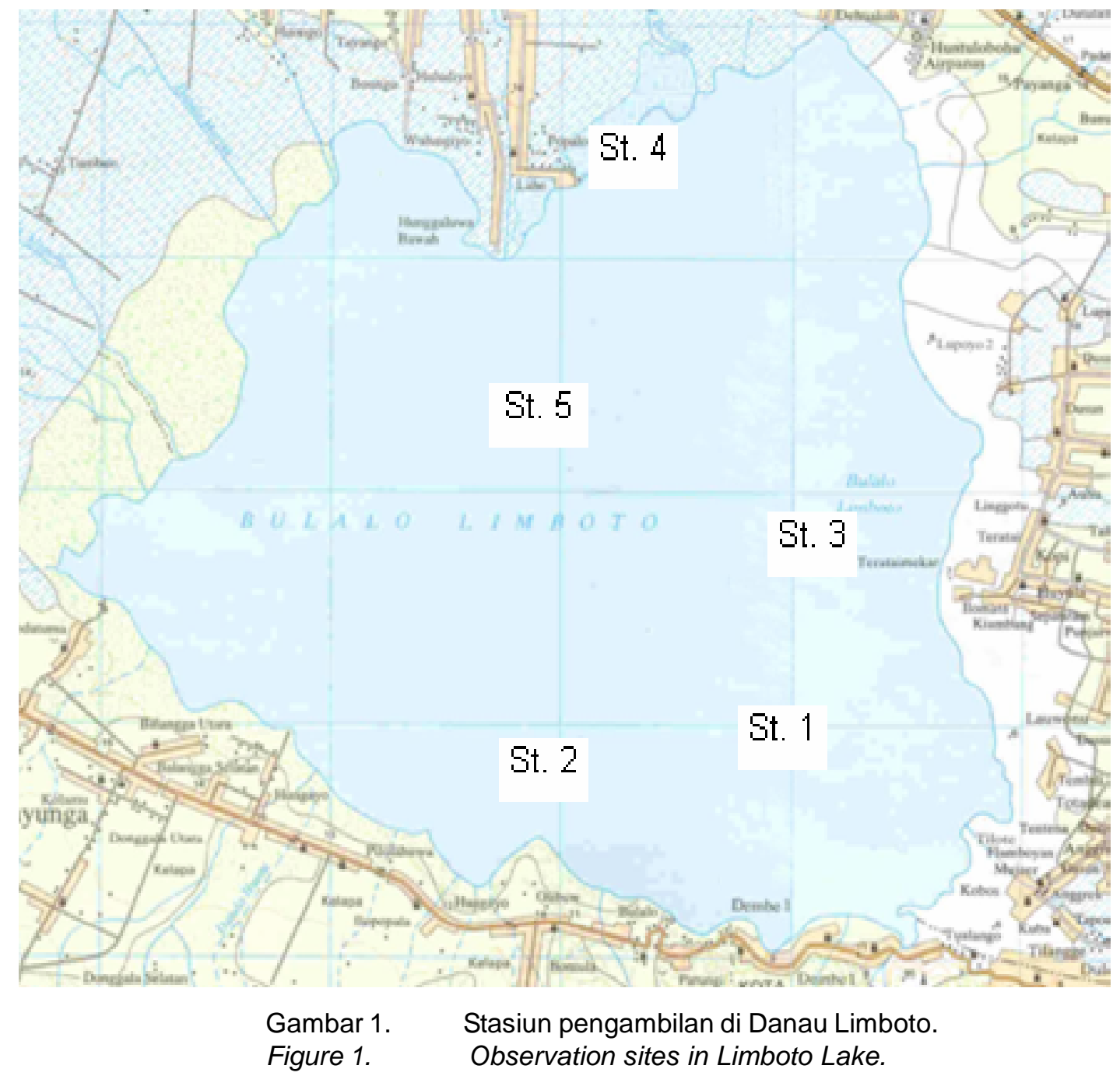

Penelitian ini bertujuan untuk mengetahui karakteristik kualitas air di Danau Limboto, Provinsi Gorontalo.

\section{BAHAN DAN METODE}

Penelitian ini dilakukan pada bulan Maret, Mei, September, dan Nopember 2006 di lima stasiun pengamatan yang masing-masing mewakili inlet, daerah budi daya, outlet, tengah danau, dan daerah yang padat tumbuhan air (Gambar 1, Tabel 1). Data dikumpulkan dengan menggunakan metode survei berstrata secara horisontal di setiap stasiun pengamatan dan secara vertikal pada kedalaman 0 (permukaan), 1, $2 \mathrm{~m}$, dan dasar perairan.

Pengambilan contoh air menggunakan kemmerer water sampler volume $5 \mathrm{~L}$. Contoh air yang diambil dimasukkan ke dalam botol contoh untuk dianalisis 
Tabel 1. Deskripsi lokasi penelitian

Table 1. Descriptions of sampling station

\begin{tabular}{cl}
$\begin{array}{c}\text { Stasiun pengamatan/ } \\
\text { Observation station }\end{array}$ & \multicolumn{1}{c}{$\begin{array}{c}\text { Deskripsi lokasi/ } \\
\text { Description of sampling station }\end{array}$} \\
\hline I & $\begin{array}{l}\text { Daerah penangkapan dengan perangkap rumpon (bibilo), daerah agak berteluk dan tidak } \\
\text { ada aktivitas transportasi. }\end{array}$ \\
II & $\begin{array}{l}\text { Daerah yang landai dan merupakan lokasi budi daya ikan dalam hampang (karamba). } \\
\text { III }\end{array}$ \\
IV & $\begin{array}{l}\text { Daerah outlet dan terdapat aktivitas penangkapan dengan alat tangkap sero. } \\
\text { Daerah inlet, terdapat tumbuhan air kangkung (Ipomoea aquatica), eceng gondok } \\
\text { V Vichhornia crassipes), dan rumput. }\end{array}$ \\
\hline
\end{tabular}

\begin{tabular}{|c|c|c|}
\hline Parameter/Parameter & Satuan/Unit & Metode/Method \\
\hline \multicolumn{3}{|l|}{ Fisika/Physical parameters } \\
\hline 1. Kecerahan Air & $\mathrm{cm}$ & Secchi disk \\
\hline 2. Suhu Air & ${ }^{\circ} \mathrm{C}$ & Termometer \\
\hline \multicolumn{3}{|l|}{ Kimia/Chemical parameters } \\
\hline 1. $\mathrm{pH}$ & & $\mathrm{pH}$ indicator solution 4 to 10 \\
\hline 2. Oksigen terlarut (Dissolved oxygen, DO) & $\mathrm{mg} / \mathrm{L}$ & DO meter YSI 55 \\
\hline 3. Karbondiokasida (Carbon dioxide, $\mathrm{CO}_{22}$ ) & $\mathrm{mg} / \mathrm{L}$ & $\mathrm{Na}_{2} \mathrm{CO}_{3} /$ Titrimetri \\
\hline 4. Total alkalinitas & $\mathrm{mg} / \mathrm{L}$ eq. $\mathrm{CaCO}_{3}$ & $\mathrm{HCl} /$ Titimetri \\
\hline 5. $\mathrm{N}-\mathrm{NO}_{3}$ & $\mathrm{mg} / \mathrm{L}$ & Brucine sulfat/Spektrofotometri \\
\hline 6. $\mathrm{N}-\mathrm{NO}_{2}$ & $\mathrm{mg} / \mathrm{L}$ & Naftilamine/Spektrofotometri \\
\hline 7. $\mathrm{N}-\mathrm{NH}_{4}$ & $\mathrm{mg} / \mathrm{L}$ & Nessler/Spektrofotomettri \\
\hline 8. $\mathrm{P}-\mathrm{PO}_{4}$ & $\mathrm{mg} / \mathrm{L}$ & $\mathrm{SnCl}_{2} /$ Spektrofotometri \\
\hline 9. Bahan organik total (Total Organic Matter, TOM) & $\mathrm{mg} / \mathrm{L}$ & Kalium permanganat/ Titrimetri \\
\hline 10. Klorofil-a & $\mathrm{mg} / \mathrm{m}^{3}$ & Tricometric/Spectrofotometri \\
\hline
\end{tabular}

di Laboratorium Loka Riset Pemacuan Stok Ikan. Parameter kualitas air diamati dengan metode berdasarkan pada American Public Health Association (1989) (Tabel 2).

Contoh air untuk pengamatan plankton diambil dengan menggunakan kemmerer water sampler, kemudian disaring dengan menggunakan plankton net no.25, dan dimasukkan ke dalam botol contoh $25 \mathrm{ml}$, serta diawetkan dalam larutan lugol. Jenis dan kelimpahan plankton diidentifikasi di bawah miskroskop dengan menggunakan buku identifikasi menurut Edmonson (1959), Needham \& Needham (1963), dan Sahlan (1982). Penentuan kelimpahan sel dilakukan dengan menggunakan metode Lackey Drop Microtransect Counting Chamber (APHA, 1989) dengan persamaan sebagai berikut:

$\mathrm{N}=\mathrm{n} \times \mathrm{A} / \mathrm{B} \times \mathrm{C} / \mathrm{D} \times 1 / \mathrm{E}$ $(1$ di mana:
$\mathrm{N}=$ jumlah total fitoplankton (ind./L)
$\mathrm{N}=$ jumlah rata-rata jumlah total individu per lapang pandang
$A=$ luas gelas penutup $\left(\mathrm{mm}^{2}\right)$
$B$ = luas satu lapang pandang $\left(\mathrm{mm}^{2}\right)$
$\mathrm{C}=$ volume air terkonsentrasi $(\mathrm{ml})$
$\mathrm{D}=$ volume air (ml) di bawah gelas penutup
$\mathrm{E}=$ volume air yang disaring $(\mathrm{I})$

Klorofil-a menyususn $1-2 \%$ dari total bobot kering fitoplankton, sehingga klorofil-a tersebut dapat digunakan sebagai indikator untuk penilaian biomassa fitoplankton (APHA, 1989). Klorofil-a mempunyai korelasi yang baik dengan efisiensi fotosintesis, biomassa fitoplankton, dan produksi fitoplankton (Brylinsky dalam Tjahjo, 2004). Analisis klorofil-a dilakukan dengan metode trikometri dan menggunakan formulasi sebagai berikut: 


\author{
Ca x volume ekstrak

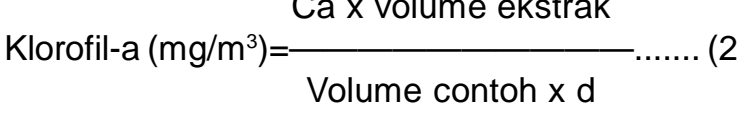 \\ $\mathrm{Ca}=11,85(\mathrm{OD} 664)-1,54$ (OD647)-0,08 (OD630)
}

di mana:

\begin{tabular}{|c|c|}
\hline $\mathrm{Ca}$ & $\begin{aligned}= & \text { konsentrasi klorofil-a } \\
& \text { dalam ekstrak (mg/L) }\end{aligned}$ \\
\hline Volume ekstrak & $\begin{aligned}= & \text { volume contoh } \\
& \text { setelah dilarutkan } \\
& \text { dalam aseton }\end{aligned}$ \\
\hline Volume sample & $\begin{aligned}= & \text { volume air yang } \\
& \text { disaring }(\mathrm{L})\end{aligned}$ \\
\hline d & $\begin{aligned}= & \text { diameter atau cela } \\
& \text { kuvet yang digunaka } \\
& (\mathrm{cm})\end{aligned}$ \\
\hline D664, OD647, OD630 & $\begin{array}{l}\text { absorban yan } \\
\text { diperiksa (cela } \\
\text { cahaya } 1 \mathrm{~cm} \text { ) pad } \\
\text { setiap panjan } \\
\text { gelombang setela } \\
\text { dikurangi denga } \\
\text { absorban pad } \\
\text { panjang gelomban } \\
750 \mathrm{~nm}\end{array}$ \\
\hline
\end{tabular}

\section{HASIL DAN BAHASAN}

Hasil analisis kualitas air di semua stasiun pengambilan contoh air di Danau Limboto menunjukkan karakteristik kualitas air di setiap stasiun penelitian tersebut. Karakteristik kualitas air di setiap stasiun penelitian ditunjukkan oleh beberapa nilai parameter seperti yang disajikan pada Tabel 3 .

\section{Kecerahan}

Kecerahan air di Danau Limboto berkisar 10 - 90 cm. Pada tahun 1993/1994, kecerahan air berkisar 15 - $125 \mathrm{~cm}$ (Sarnita et al., 1994). Setelah 12 tahun (1994 - 2006), kecerahan air di Danau Limboto mengalami penurunan sekitar $35 \mathrm{~cm}$. Kecerahan terendah teramati di stasiun I pada bulan Nopember. Pada bulan ini, kedalaman maksimal di stasiun I hanya $0,5 \mathrm{~m}$ sehingga proses turbulensi air oleh angin menyebabkan kekeruhan meningkat sehingga kecerahannya rendah. Hal ini kemungkinan karena pada bulan tersebut perairan Danau Limboto sedang surut yang tercermin dari kedalaman maksimalnya hanya $0,5 \mathrm{~m}$. Kecerahan mempengaruhi penetrasi cahaya ke perairan yang berpengaruh pada fotosintesis fitoplankton yang akan menghasilkan oksigen perairan. Oksigen terlarut hasil fotosintesis berkisar $65 \%$ dari total oksigen perairan (Schmittou, 1991).

Kecerahan air dari bulan Maret - Nopember mengalami penurunan di semua stasiun (Gambar 2). $\mathrm{Hal}$ ini diduga karena terjadinya penyusutan luas dan volume air akibat dari surutnya air danau. Penyusutan luas dan volume air akibat surutnya air danau diduga dapat mempermudah proses pengadukan dasar perairan yang berakibat banyaknya partikel-partikel dasar perairan ke kolom air sehingga menghalangi penetrasi cahaya. Penyurutan air danau dapat disebabkan juga oleh cuaca panas yang menyebabkan terjadinya evapotranspirasi. Demikian juga kedalaman maksimal yang juga menurun. Kecerahan air yang rendah ini juga terjadi di Danau Tempe $(18-50 \mathrm{~cm})$, dan juga keruh yang mungkin akibat siltasi dari sungai-sungai yang masuk ke danau atau pengadukan dasar danau yang relatif dangkal (Suwignyo, 1978). Terjadi juga penurunan kedalaman Danau Limboto, pada tahun 1934 kedalaman sekitar berkisar 14 - 20 m dan menurun menjadi 2 - 4 m pada 1999. Pada saat penelitian, kedalaman maksimal yang terukur pada beberapa stasiun pengamatan adalah 0,2 - 3,5 m (Gambar 3). Penurunan kedalaman ini juga terjadi di Danau Tondano, Sulawesi Utara pada tahun 1934 mencapai $40 \mathrm{~m}$ dan setelah 62 tahun yaitu tahun 1996 hanya sekitar 15 m (Kumuruur, 2002).

\section{Suhu Air}

Rata-rata suhu perairan berkisar $28,8-30,4^{\circ} \mathrm{C}$. Suhu sekitar $29-32^{\circ} \mathrm{C}$ akan mendukung kehidupan fitoplankton (Ray \& Rao dalam Pratiwi et al., 2000). Hasil penelitian tahun 1993/1994, suhu air berkisar $28-33^{\circ} \mathrm{C}$ (Sarnita et al., 1994), artinya selama 12 tahun tidak terjadi perbedaan suhu yang mencolok. Warna airnya adalah hijau dan coklat; warna hijau menunjukkan kandungan fitoplankton, sedangkan warna coklat kemungkinan adanya partikel tanah yang berasal dari erosi dan pengadukan lapisan dasar. Danau ini termasuk dangkal dengan kedalaman sekitar 0,5 - 3,5 m sehingga proses pengadukan lapisan dasar dapat terjadi karena adanya angin dan perahu motor yang mengakibatkan gelombang.

\section{Derajat Keasaman}

Rata-rata $\mathrm{pH}$ perairan berkisar 7 - 8; artinya termasuk perairan netral cenderung alkalis. Hasil ini tidak jauh berbeda dengan hasil pengamatan tahun 1993/1994 yang berkisar 7 - 8,4 (Sarnita et al., 1994). 


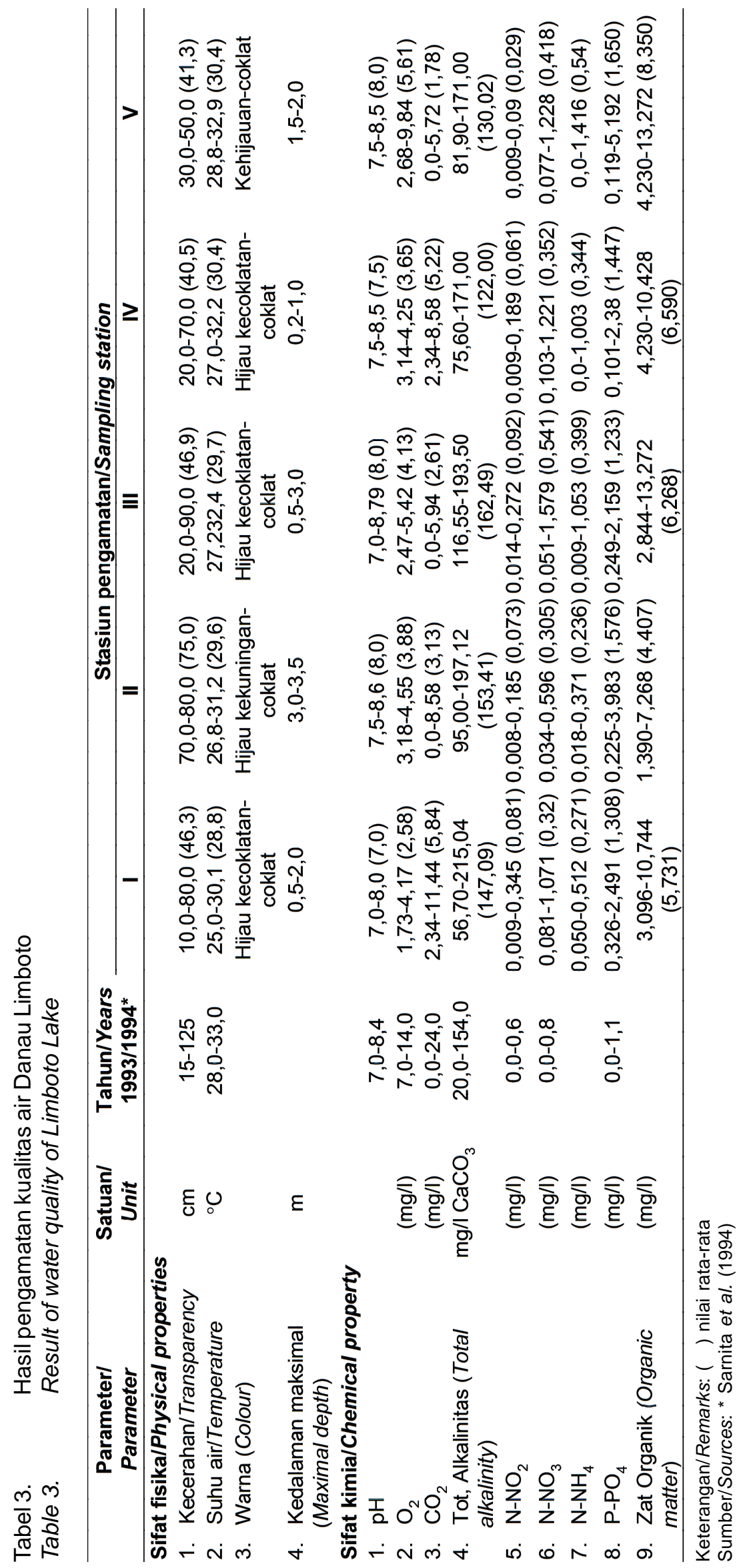




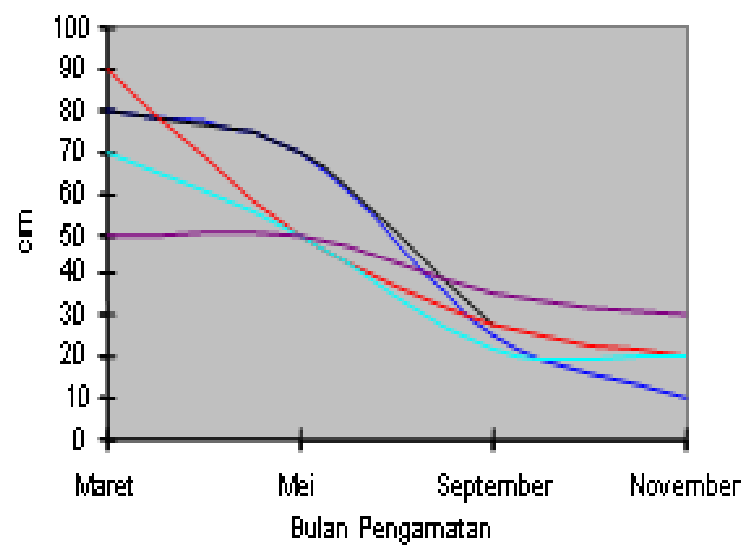

$\longrightarrow \mathrm{St} \longrightarrow \mathrm{It} \|-\mathrm{St} \mathrm{II}-\mathrm{St} \mathrm{IV}=\mathrm{St} \mathrm{V}$

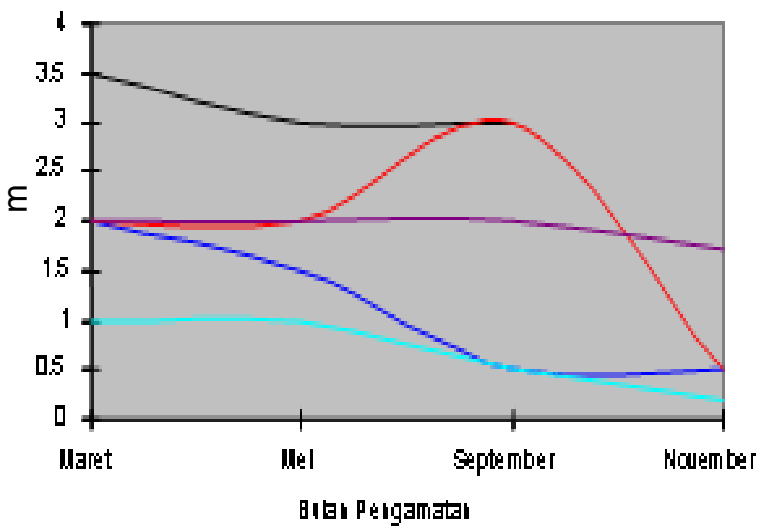

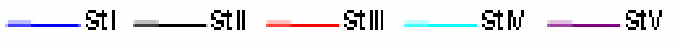

Gambar 2. Tingkat kecerahan Danau Limboto. Gambar 3. Kedalaman maksimal Danau Limboto. Figure 2. Transparency level of Limboto Lake. Figure 3. Maximum depth of Limboto Lake.

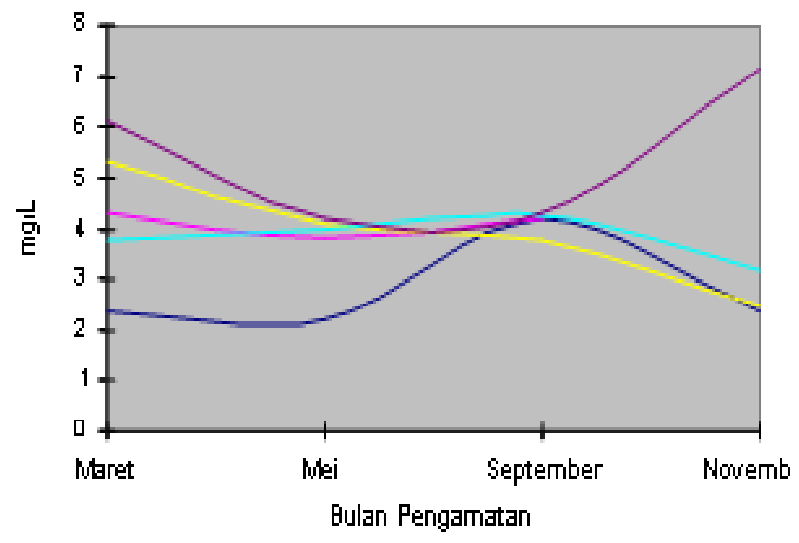

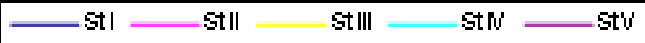

Gambar 4. Oksigen terlarut di permukaan air. Figure 4. Oxygen content in surface water.

\section{Alkalinitas Total}

Total alkalinitas di semua stasiun berkisar 56,70 - 215,04 mg/L eq $\mathrm{CaCO}_{3}$ dengan nilai rata-rata 143 $\mathrm{mg} / \mathrm{Leq} \mathrm{CaCO}_{3}$. Hal ini berarti bahwa perairan Danau Limboto termasuk perairan sadah. Hasil penelitian tahun 1993/1994 menunjukkan bahwa alkalinitas total berkisar 20 - $154 \mathrm{mg} / \mathrm{L}$ eq $\mathrm{CaCO}_{3}$ (Sarnita et al., 1994). Berarti ada peningkatan nilai alkalinitas yang diduga karena Danau Limboto terletak di daerah pegunungan kapur yang agak gundul sehingga masukkan ion $\mathrm{Ca}^{2+}$ dapat terjadi melalui proses erosi.

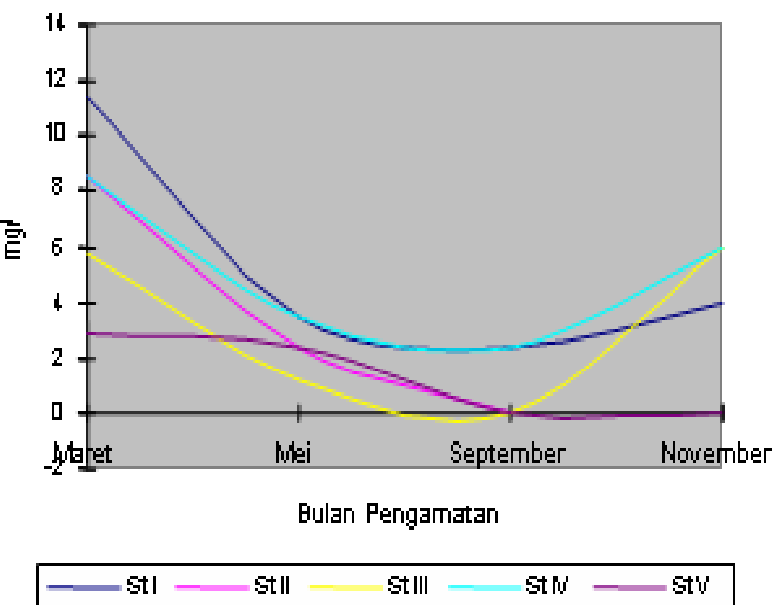

Gambar 5. Karbondioksida bebas di permukaan. Figure 5. Free carbondioxide content in surface water.

\section{Oksigen Terlarut dan Karbondioksida Bebas}

Konsentrasi oksigen terlarut berkisar 1,73 - 9,84 $\mathrm{mg} / \mathrm{L}$ dengan nilai rata-rata $4,62 \mathrm{mg} / \mathrm{L}$, sedangkan hasil penelitian tahun 1993/1994 menunjukkan bahwa oksigen terlarut berkisar 7 - $14 \mathrm{mg} / \mathrm{L}$ (Sarnita et al., 1994). Berarti ada penurunan konsentrasi oksigen terlarut selama selang waktu 12 tahun, diduga karena kecerahan yang semakin menurun, ada proses dekomposisi bahan organik yang berasal dari tumbuhan air yang telah mati, serta peningkatan kegiatan budi daya ikan yang dapat meningkatan 
masukan bahan organik ke perairan. Pada tahun 2006, oksigen terlarut terendah terjadi di stasiun I pada bulan Maret di dasar perairan. Hal ini diduga karena daerah ini merupakan lokasi penangkapan ikan dengan rumpon air eceng gondok yang padat sehingga menghalangi penetrasi cahaya ke lapisan bawah yang menyebabkan deplesi oksigen. Konsentrasi oksigen permukaan berfluktuasi (Gambar 4).

Konsentrasi karbondioksida bebas berkisar 0 $8,58 \mathrm{mg} / \mathrm{L}$, sedangkan pada tahun 1993/1994 berkisar 0 - $24 \mathrm{mg} / \mathrm{L}$ (Sarnita et al., 1994). Terjadinya penurunan konsentrasi $\mathrm{CO}_{2}$ bebas setelah 12 tahun (tahun 1993/1994 - 2006). Konsentrasi karbondioksida permukaan juga berfluktuasi (Gambar 5). Berdasarkan pada Peraturan Pemerintah No.82 tahun 2001 tentang Pengelolaan Kualitas Air dan Pengendalian Pencemaran Air, oksigen terlarut untuk kegiatan perikanan minimal $3 \mathrm{mg} / \mathrm{L}$ (Kementerian Lingkungan Hidup, 2004). Konsentrasi $\mathrm{CO}_{2}$ lebih dari $10 \mathrm{mg} / \mathrm{L}$ yang disertai dengan oksigen terlarut yang rendah dapat menyebabkan kematian beberapa jenis ikan (Adji et al., 2005) sehingga berdasarkan pada kedua hal tersebut, maka perairan Danau Limboto layak untuk kegiatan perikanan.

\section{Hara $\mathbf{N}$ dan $\mathbf{P}$}

Nutrien nitrogen dan fosfor di perairan Danau Limboto dapat berasal dari limbah domestik, limbah pakan ikan budi daya dalam hampang, erosi dari perbukitan sekitarnya, limbah pertanian, serta hasil dekomposisi tumbuhan air yang telah mati. Nilai $\mathrm{N}$ $\mathrm{NO}_{2}$ berkisar $0,008-0,345 \mathrm{mg} / \mathrm{L}$, konsentrasi tertinggi terjadi di stasiun I pada bulan Nopember. Konsentrasi $\mathrm{N}-\mathrm{NO}_{3}$ pada tahun 2006 berkisar 0,034 - 1,596 mg/L tertinggi di stasiun III pada bulan September. Konsentrasi $\mathrm{N}-\mathrm{NH}_{4}$ berkisar 0 - 1,053 mg/L, tertinggi di stasiun III pada bulan Nopember. Pada bulan September - Nopember, air Danau Limboto sedang surut sehingga volume airnya lebih sedikit akibatnya konsentrasi nutrien lebih tinggi. Stasiun III merupakan outlet danau, sehingga membawa partikel-partikel dan nutrien dari danau dan ke luar menuju laut lepas. Konsentrasi ortophospat berkisar 0,101-5,192 mg/ $\mathrm{L}$, tertinggi di stasiun $\mathrm{V}$ pada bulan Mei. Hal ini kemungkinan berasal dari limpasan dari hutan dan perbukitan sekitar danau. Hasil pengukuran tahun 1993/1994, nilai N-NO 3 berkisar 0 - 0,8 mg/L dan P$\mathrm{PO}_{4}$ berkisar $0-1,1 \mathrm{mg} / \mathrm{L}$ (Sarnita et al., 1994) yang berarti bahwa ada peningkatan konsentrasi $\mathrm{N}-\mathrm{NO}_{3}$ dan $\mathrm{P}-\mathrm{PO}_{4}$ yang diduga karena adanya aktivitas budi daya ikan, limpasan dari tanah pertanian yang masuk ke perairan dan limbah rumah tangga seperti deterjen.

Berdasarkan pada hasil pengukuran nutrien, kecerahan, klorofil-a dan kelimpahan plankton di Danau Limboto, maka danau ini dapat dikatakan sebagai danau yang subur dan telah mengalami eutrofikasi. Berdasarkan pada Tabel 4 dan 5, Danau Limboto dapat digolongkan sebagai eutrofik dan hipertrofik.

Tabel 4. Tingkat trofik setiap stasiun pangamatan di Danau Limboto

Table 4. Trophic level of each research station of Limboto Lake

\begin{tabular}{|c|c|c|c|c|c|}
\hline \multirow{2}{*}{$\begin{array}{l}\text { Lokasi/ } \\
\text { Location }\end{array}$} & \multicolumn{5}{|c|}{ Stasiun/Station } \\
\hline & St I & St II & St III & St IV & St V \\
\hline Kecerahan (m) & $\begin{array}{l}10-80(46,3) \\
\text { (hipertrofik) }\end{array}$ & $\begin{array}{c}27,5-80(59,2) \\
\text { (hipertrofik) }\end{array}$ & $\begin{array}{l}20-90(46,9) \\
\text { (hipertrofik ) }\end{array}$ & $\begin{array}{c}20-70(40,5) \\
\text { (hipertrofik) }\end{array}$ & $\begin{array}{c}30-50(41,3) \\
\text { (hipertrofik) }\end{array}$ \\
\hline $\mathrm{N}-\mathrm{NO}_{3}(\mathrm{mg} / \mathrm{L})$ & $\begin{array}{c}0,081-1,071(0,32) \\
\text { (eutrofik) }\end{array}$ & $\begin{array}{c}0,034-0,596 \\
(0,305) \text { (eutrofik) }\end{array}$ & $\begin{array}{c}0,051-1,579 \\
(0,541) \text { (eutrofik) }\end{array}$ & $\begin{array}{c}0,103-1,221 \\
(0,352) \text { (eutrofik) }\end{array}$ & $\begin{array}{c}0,077-1,228 \\
(0,418) \text { (eutrofik) }\end{array}$ \\
\hline $\mathrm{P}-\mathrm{PO}_{4}(\mathrm{mg} / \mathrm{L})$ & $\begin{array}{c}\text { 0,326-2,491 }(1,308) \\
\text { (eutrofik) }\end{array}$ & $\begin{array}{c}0,225-3,983 \\
(1,576) \text { (eutrofik) }\end{array}$ & $\begin{array}{c}0,249-2,159 \\
(1,233) \text { (eutrofik) }\end{array}$ & $\begin{array}{c}0,101-2,38 \\
(1,447) \text { (eutrofik) }\end{array}$ & $\begin{array}{c}0,119-5,192 \\
(1,65) \text { (eutrofik) }\end{array}$ \\
\hline Klorofil-a $\left(\mathrm{mg} / \mathrm{m}^{3}\right)$ & $\begin{array}{c}\text { 13,05-24,6 }(21,1) \\
\text { (eutrofik) }\end{array}$ & $\begin{array}{l}14,1-25,5(18,8) \\
\text { (eutrofik) }\end{array}$ & $\begin{array}{c}11,9-24,9(17,1) \\
\text { (eutrofik) }\end{array}$ & $\begin{array}{c}16,9-29,3(21,9) \\
\text { (eutrofik) }\end{array}$ & $\begin{array}{c}14,4-32,3(22,5) \\
\text { (eutrofik) }\end{array}$ \\
\hline $\begin{array}{l}\text { Kelimpahan } \\
\text { plankton (ind. per I) }\end{array}$ & $\begin{array}{c}15.090-295.764 \\
(135.520) \\
\text { (eutrofik) }\end{array}$ & $\begin{array}{c}11.066-208.242 \\
(71.175) \text { (eutrofik) }\end{array}$ & $\begin{array}{c}9.054-249.548 \\
\text { (97.438) (eutrofik) }\end{array}$ & $\begin{array}{c}\text { 18.108-186.110 } \\
(128.442) \\
\text { (eutrofik) }\end{array}$ & $\begin{array}{c}\text { 34.204-208.302 } \\
(118.142) \\
\text { (eutrofik) }\end{array}$ \\
\hline Status trofik & Eutrofik-hipertrofik & Eutrofik-hipertrofik & Eutrofik-hipertrofik & $\begin{array}{l}\text { Eutrofik- } \\
\text { hipertrofik }\end{array}$ & Eutrofik-hipertrofik \\
\hline
\end{tabular}


Tabel 5. Kriteria kualitas air untuk mengevaluasi tingkat trofik Danau Limboto

Table 5. Water quality criteria to evaluating trophic level status of Limboto Lake

\begin{tabular}{|c|c|c|c|c|c|}
\hline \multirow{2}{*}{$\begin{array}{l}\text { Parameter/ } \\
\text { Parameter }\end{array}$} & \multicolumn{4}{|c|}{ Status trofik/Trophic level } & \multirow[b]{2}{*}{ Sumber/Source } \\
\hline & Oligotrofik & Mesotrofik & Eutrofik & Hipertrofik & \\
\hline Kecerahan/Transparency (m) & $\geq 6$ & $\geq 4$ & $\geq 1$ & $<0,5$ & Wetzel (2001) \\
\hline $\mathrm{N}-\mathrm{NO}_{3}(\mathrm{mg} / \mathrm{l})$ & $<0,1$ & $0,1-0,2$ & $>0,2$ & & Golman \& Horne (1983) \\
\hline $\mathrm{P}-\mathrm{PO}_{4}(\mathrm{mg} / \mathrm{l})$ & $0,003-0,01$ & $0,011-0,03$ & $0,031-0,1$ & & $\begin{array}{l}\text { Vollenweider dalam Effendi } \\
\text { (2003) }\end{array}$ \\
\hline $\begin{array}{l}\text { Klorofil-aChlorophyll-a } \\
\left(\mathrm{mg} \mathrm{m}^{-3}\right)\end{array}$ & $0,3-3$ & $2-15$ & $10-500$ & & Wetzel (2001) \\
\hline $\begin{array}{l}\text { Kelimpahan plankton/ } \\
\text { Plankton abundance (ind/l) }\end{array}$ & $<2.000$ & $2.000-15.000$ & $>15.000$ & & Lander dalam Basmi (1991) \\
\hline
\end{tabular}

\section{Jenis dan Kelimpahan Plankton}

Kelimpahan fitoplankton di suatu perairan dipengaruhi oleh beberapa parameter lingkungan dan karakteristik fisiologis. Komposisi dan kelimpahan fitoplankton akan berubah pada berbagai tingkatan sebagai respon terhadap perubahan-perubahan kondisi lingkungan baik fisik, kimia, maupun biologi (Reynolds et al., 1984). Faktor penunjang pertumbuhan fitoplankton sangat kompleks dan saling berinteraksi antara satu dengan lainnya. Contohnya adalah kelimpahan fitoplankton terkait dengan intensitas cahaya, oksigen terlarut, stratifikasi suhu, dan ketersediaan unsur hara nitrogen dan fosfor, dan faktor biologi seperti pemangsaan oleh hewan, mortalitas alami, dan dekomposisi (Goldman \& Horne, 1983).

Hasil penelitian tahun 1993/1994 menunjukkan bahwa kelimpahan plankton berkisar 930 - 1.700 ind./
L (Sarnita et al., 1994), sedangkan hasil penelitian tahun 2006 (Tabel 6), kelimpahan plankton berkisar 9.054 - 295.764 ind./L dengan rata-rata $7,1 \times 10^{4}$ $1,4 \times 10^{5}$ ind./L yang terdiri atas fitoplankton dan zooplankton yang artinya ada peningkatan kelimpahan plankton yang diduga disebabkan oleh adanya peningkatan hara atau nutrien. Pada bulan Nopember, stasiun I mempunyai konsentrasi N-NO $(1,071 \mathrm{mg} /$ $\mathrm{L}), \mathrm{N}-\mathrm{NH}_{4}(0,512 \mathrm{mg} / \mathrm{L})$, dan $\mathrm{P}_{-}-\mathrm{PO}_{4}(1,405 \mathrm{mg} / \mathrm{L})$ yang sesuai untuk pertumbuhan fitoplankton secara optimal (Mackentum, 1969 dalam Yuliana \& Thamrin, 2006). Kandungan nitrat untuk pertumbuhan optimal fitoplankton berkisar $0,9-3,5 \mathrm{mg} / \mathrm{L}$ dan ortofosfat 0,09 $-1,8 \mathrm{mg} / \mathrm{L}$. Menurut Raymon (1980), fosfat merupakan salah satu unsur penting dalam pertumbuhan dan metabolisme tubuh diatom.

Jenis-jenis plankton yang banyak ditemukan di Danau Limboto antara lain disajikan pada Tabel 7.

Tabel 6. Kelimpahan plankton pada setiap stasiun pengamatan di Danau Limboto

Table 6. Plankton abundance at each sampling station of Limboto Lake

\begin{tabular}{lcccccc}
\hline & Satuan / & \multicolumn{4}{c}{ Stasiun pengamatan/Observation station } \\
\cline { 3 - 7 } & Unit & I & II & III & IV & V \\
\hline 1. Kelimpahan plankton/Plankton & Ind/I & $15.090-$ & $11.066-$ & $9.054-249.548$ & $18.108-$ & $34.204-$ \\
$\quad$ Abundance & & 295.764 & 208.242 & $(97.438)$ & 186.110 & 208.302 \\
& & $(135.520)$ & $(71.175)$ & & $(128.442)$ & $(118.142)$ \\
2. Jumlah klas/Number of classes & & $4-8$ & 5 & $5-7$ & $4-6$ & $2-7$ \\
$\begin{array}{l}\text { 3. Jumlah genera/Number of } \\
\text { generas }\end{array}$ & & $9-20$ & $10-23$ & $5-28$ & $6-26$ & $6-23$ \\
\hline
\end{tabular}

Tabel 7.

Table 7.

Kelas dan genus plankton yang banyak ditemukan di Danau Limboto Class and genera of plankton found dominantely in Limboto Lake

\begin{tabular}{ll}
\hline \multicolumn{1}{c}{ Kelas/Class } & \multicolumn{1}{c}{ Genus/Genera } \\
\hline Chlorophyceae & Ankistrodesmus, Chlorella, Pediastrum, Protococcus, Tribonema, dan Ulothrix \\
Cyanophyceae & Mycrocystis, Oscillatoria, Spirulina, dan Rivularia \\
Bacillariophyceae & Melosira, Synedra, Cymbella, Tabellaria, dan Navicula \\
Dinophyceae & Peridinium dan Mallomonas \\
Euglenaphyceae & Phacus \\
Copepoda & Cyclop \\
Cladocera & Nauptilus \\
Rotifera & Branchionus, Polyanthra, dan Keratella \\
Protozoa & Actinophris dan Synura \\
Bacteria & Micrococcus dan Siderocapsa \\
\hline
\end{tabular}


Beberapa genus plankton yang ditemukan di Danau Limboto bersifat merugikan dan menimbulkan permasalahan di perairan, yaitu Microcystis, Oscillatoria, Ulothrix, Synedra, Navicula, Diatoma, Staurastrum, dan Phacus (Suriawiria, 1996). Microcystis, Anabaena, dan Oscillatoria merupakan alga biru penghasil racun microsistin (Chorus \& Bartran, 1999), bahkan Oscillatoriajuga menghasilkan neurotoksin (anatoxin-a dan homoanatoxin-a) yang berbahaya bagi manusia dan hewan (Hamill, 2001).

\section{KESIMPULAN}

Berdasarkan pada suhu, $\mathrm{pH}$, alkalinitas total, oksigen terlarut, dan karbondioksida bebas, maka kualitas air Danau Limboto mendukung kegiatan perikanan. Berdasarkan pada tingkat kecerahan air, $\mathrm{N}-\mathrm{NO} 3, \mathrm{P}-\mathrm{PO} 4$, klorofil-a, dan kelimpahan plankton, maka danau ini termasuk ke dalam danau eutrofik dan hipertrofik (subur). Perlu kewaspadaan terhadap muncul fitoplankton beracun seperti Microcystis dan Anabaena yang berbahaya bagi ikan di danau.

\section{PERSANTUNAN}

Kegiatan dari hasil riset konservasi dan rehabilitasi Danau Limboto, Gorontalo, T. A. 2006, di Loka Riset Pemacuan Stok Ikan, Jatiluhur-Purwakarta.

\section{DAFTAR PUSTAKA}

Adjie, S., A. D. Utomo, N. Muflihah, \& A. Wibowo. 2005. Pengamatan kualitas air fisika kimia perairan Bengawan Solo. Prosiding Seminar Nasional Tahunan Hasil Penelitian Perikanan dan Kelautan. Jurusan IImu Perikanan dan Kelautan. Fakultas Pertanian. Universitas Gadjah Mada. Yogyakarta. MSP. p: 72-77.

American Public Health Association. 1989. Standard Methods for the Examination of Water and Waste Water including Bottom Sediment and Sludges. 12-th ed American Publish Health Association Inc. New York. $1.134 \mathrm{pp}$

Anonimus. 2008. Pengelolaan danau dan waduk di Indonesia. Pusat Penelitian dan Pengembangan Sumber daya Alam. Diakses tanggal 1 Agustus 2008 dari www.pusair-pu,go,id/artikel/kesatu. pdf.

Chorus, I. \& J. Bartran. 1999. Toxic Cyanobacteria in Water: A Guide to Their Public Health Consequences Monitoring and Management. W. H. O. London. 440 pp.
Effendie, M. I. 2002. Metode Biologi Perikanan.Yayasan Dewi Sri. Bogor. 112 pp.

Golman, C. R. \& A. J. Horne. 1983. Limnology. Mcgraw Hill Int. Book Comp. London. 464 pp.

Hamill, K. D. 2001. Toxicity in benthic freshwater cyanobacteria (blue-green alga) first observation in New Zealand. New Zealand Journal of Marine and Freshwater Research. Vol.35. 1.057-1.059.

Kumuruur, V. 2002. Aspek strategis pengelolaan Danau Tondano Secara Terpadu. Ekoton. Vol.2 (1): 73-80.

Kementerian Lingkungan Hidup. 2004. Himpunan peraturan di bidang pengelolaan lingkungan hidup dan penegakan hukum lingkungan. Jakarta.

Needham, J. G. \& P. R. Needham. 1963. A guide to the study of freshwater biology. Fifth Edition. Revised and Enlarged. Holden Day. Inc. San Fransisco. $180 \mathrm{p}$.

Lehmusluoto, P. 2000.Management of lakes in tropics focus on Indonesia. Newsletter and Technical Publications Freshwater Management Series. No.8 Proceedings of the Workshop on Lake Management and Eutrophication Control for Donghu Lake.

Pratiwi, N. T. M, K. Praptokardiyo, \& N. Indrayani. 2000. Tingkat kesuburan perairan Situ Ciguded, Kabupaten Bogor, Jawa Barat. Prosiding Semi Loka Nasional Pengelolaan dan Pemanfaatan Danau dan Waduk. Jurusan Perikanan Fakultas Pertanian. Universitas Padjajaran. Bandung. 199$210 \mathrm{pp}$.

Raymond, J. E. G. 1980. Plankton and Productivity in the Ocean. Mc. Milla Co. New York. 489pp.

Reynol, C. S., J. G. Tundisi, \& K. Hino. 1984. Observation on a metalimnetic phytoplankton population in a stably stratified tropical lake. Arch. Hydrobyo. Argentina. 97: 7-17.

Tjahjo, D. W. H. 2004. Kemantapan hasil tangkapan, keterkaitan dengan sintasan, pertumbuhan, dan intensitas penangkapan udang galah yang ditebarkan di Waduk Darma, Kuningan, Jawa Barat. Tesis. Institut Pertanian Bogor. Bogor. 
Schmittou, H. R. 1991. Cage Culture: A Method of Fish Production in Indonesia. Fisheries Research and Development Project. Central Research Institute for Fisheries. Jakarta. 114 pp.

Suwignyo P. 1978. Kasus Perencanaan Danau Tempe ditinjau dari Aspek Biologi atau Ekologi Perairannya. Seameo Biotrop. Bogor. Indonesia. $55 \mathrm{pp}$.

Suriawiria. 1996. Mikrobiologi Air: Pendekatan Biologi dalam Pendugaan Pencemaran Perairan. Andi Offset. Yogyakarta. $330 \mathrm{pp}$.
Yuliana \& Tamrin. 2006. Struktur komunitas dan kelimpahan fitoplankton dalam kaitannya dengan parameter fisika kimia perairan di Danau Laguna Ternate, Maluku Utara. Dalam Prosiding Seminar Nasional Limnologi 2006: Pengelolaan Sumber Daya Perairan Darat secara Terpadu di Indonesia. Pusat Penelitian Limnologi. Jakarta. p:200-209.

Whitten, A. J., Mustafa, \& G. S. Hendersen. 1988. The Ecology of Sulawesi. Gadjah Mada University Press. Yogyakarta. 221 pp. 